\title{
Minimalisasi Risiko Kredit (NPL) Pada Fintach Peer to Peer Lending melalui Kewajiban Pelaporan SLIK OJK
}

\author{
Renova Hutapea \\ Magister Ilmu Hukum, Fakultas Hukum, Universitas Indonesia \\ Email : renova.hutapea@ui.ac.id
}

\begin{abstract}
The development of peer to peer lending fintech in Indonesia is very rapid in supporting increased financial inclusion. In line with the increase in the value of loans channeled through fintech peer to peer lending, the NPL credit ratio also continues to increase. For this reason, the supervisory function of the Financial Services Authority (OJK) is very important for the development of the implementation of lending carried out by peer to peer lending operators that are registered and licensed at the OJK. The research method used is normative legal research method, which will conduct research on various related legal rules. The legal research method is a method that refers to applicable laws and regulations with an analytical approach. The result of this research is one of the efforts to minimize the increase in credit risk (NPL) in the peer to peer lending fintech industry, namely by taking effective preventive action through assessing the character of potential loan recipients from credit information obtained in the Financial Information Service System (SLIK). Therefore, as a form of supervision from OJK on the peer to peer lending fintech industry, it is necessary to regulate the reporting obligations for each fintech lending provider at the SLIK so that access to comprehensive credit information can provide a better and more accurate credit scoring process to maintain the quality of loans which is funneled.
\end{abstract}

\section{Keywords : Fintech, Peer to Peer Lending, Credit Risk}

Abstrak. Perkembangan dari Fintech peer to peer lending di Indonesia sangat pesat dalam mendukung peningkatan inklusi keuangan. Seiring dengan peningkatan nilai pinjaman yang disalurkan melalui fintech peer to peer lending, ratio kredit NPL juga terus meningkat. Untuk itu fungsi pengawasan dari Otoritas Jasa Keuangan (OJK) sangat penting terhadap perkembangan dari pelaksanaan penyaluran pinjaman yang dilakukan oleh penyelenggara peer to peer lending yang telah terdaftar dan berizin di OJK. Adapun metode penelitian yang digunakan adalah metode penelitian hukum normatif, yang akan melakukan penelitian terhadap berbagai aturan hukum yang terkait. Metode penelitian hukum adalah metode yang mengacu pada hukum dan peraturan perundangundangan yang berlaku dengan pendekatan analitis. Hasil dari satu penelitian ini adalah salah satu upaya meminimalisasi peningkatan risiko kredit (NPL) pada industri fintech peer to peer lending yaitu dengan melakukan tindakan preventif yang efekfif melalui penilaian karakter calon penerima pinjaman dari informasi perkreditan yang diperoleh pada Sistem Layanan Informasi Keuangan (SLIK). Oleh karenanya, sebagai bentuk pengawasan dari OJK terhadap industri fintech peer to peer lending dibutuhkan pengaturan mengenai kewajiban pelaporan bagi setiap penyelenggara fintech lending pada SLIK sehingga dengan akses informasi perkreditan yang komprehensif dapat memberikan proses credit scoring yang lebih baik dan akurat demi terjaganya kualitas dari pinjaman yang disalurkan.

\section{Kata Kunci : Fintech, Peer to Peer Lending, Risiko Kredit}

\section{PENDAHULUAN}

Pada saat ini penggunaan teknologi informasi dan inovasi di sektor jasa keuangan di Indonesia mengalami perkembangan yang sangat signifikan. Beragam layanan keuangan yang memanfaatkan teknologi informasi atau yang disebut sebagai Financial Technology (Fintech) telah menjadi hal yang umum di masyarakat, seperti layanan pada industri perbankan, asuransi, pasar modal atau lembaga pembiayaan dan investasi. Melihat berbagai peluang pada produk dan jasa keuangan tersebut 
untuk dapat semakin mempermudah dan mempercepat akses ke masyarakat, perusahaanperusahaan Fintech di Indonesia pun semakin berkembang dengan mengandalkan berbagai inovasi dan teknologi yang mempertimbangkan keunggulan aspek penghematan biaya, kecepatan, dan kemudahan dalam menggunakan produk dan jasa keuangan. Adapun berbagai jenis Fintech telah berkembang di Indonesia seperti digital payment yang memberikan layanan berupa pembayaran transaksi secara online, financing and investment yang memberikan pinjaman dana dan peluang bagi investor/pemberi dana, account aggregator yang menawarkan layanan yang dapat mengakomodasi seluruh transaksi perbankan, Information and Feeder Site yang memberikan layanan perbandingan informasi produk atau jasa sektor jasa keuangan, personal finance yang menawarkan layanan perencanaan keuangan.

Salah satu jenis Fintech yang saat ini paling banyak digunakan di Indonesia adalah fintech pada sektor financing and investment yang dikenal dengan Peer to Peer Lending ( $P 2 P$ Lending). Hal ini dikarenakan Peer to Peer Lending menjawab kebutuhan berbagai lapisan masyarakat Indonesia yang belum terjangkau oleh institusi keuangan yang ada. Berdasarkan data statistik yang dimiliki Otoritas Jasa Keuangan (OJK) periode Juli 2020, terdapat 158 perusahaan Fintech Lending yang telah terdaftar/berizin. Peer to Peer Lending pertama kali diperkenalkan oleh Zopa di Inggris pada tahun 2005. Peer to Peer Lending adalah sebuah platform teknologi yang mempertemukan secara digital antara Peminjam yang membutuhkan modal usaha dengan Pemberi Pinjaman. Peer to peer lending dapat dikatakan menjadi wadah berinvestasi dan peminjaman dana bagi masyarakat.

Di Indonesia, platform peer to peer lending sejatinya telah ada dalam masyarakat sebelum OJK menerbitkan Peraturan Otoritas Jasa Keuangan No. 77/POJK.01/2016 tentang Layanan Pinjam Meminjam Uang Berbasis Teknologi Informasi. POJK tersebut menjelaskan bahwa peer to peer lending merupakan penyelenggaraan layanan jasa keuangan untuk mempertemukan pemberi pinjaman dengan penerima pinjaman dalam rangka melakukan perjanjian pinjam meminjam dalam mata uang rupiah secara langsung melalui sistem elektronik dengan menggunakan jaringan internet.

Kehadiran fintech peer to peer lending menjawab tingginya kebutuhan masyarakat Indonesia khususnya yang belum bankable dan undeserved untuk diberikan fasilitas pinjaman oleh perbankan. Adanya kemudahan dalam proses pemberian pinjaman yang ditawarkan oleh perusahaan fintech lending membuat perkembangan fintech peer to peer lending di Indonesia sampai dengan saat ini sangat signifikan, dapat dilihat bahwa berdasarkan data statistik dari OJK periode Juli 2020, penyaluran Fintech lending telah mencapai Rp 116,97 Triliun atau meningkat sebesar $134,91 \%$ dari tahun 2019. Hal ini menunjukkan pertumbuhan yang sangat signifikan baik dari segi nilai penyaluran pinjaman maupun dari segi jumlah rekening atau jumlah peminjam dari peminjam maupun pemberi pinjaman. Perkembangan penyaluran pinjaman yang sangat signifikan tersebut juga telah berimplikasi pada pertumbuhan ekonomi Indonesia sebesar $0,45 \%$ dan berkontribusi terhadap Produk Domestik Bruto lebih dari Rp.60 triliun, berdasarkan hasil penelitian yang diperoleh Institute for Development of Economics and Finance (Indef.

Dengan melihat perkembangan dan kontribusi positif dari Fintech peer to peer lending di Indonesia tersebut, sangatlah relevan untuk memperhatikan bagaimana kualitas kredit dari pinjaman yang telah disalurkan oleh perusahaan fintech lending di Indonesia.

TWP 90
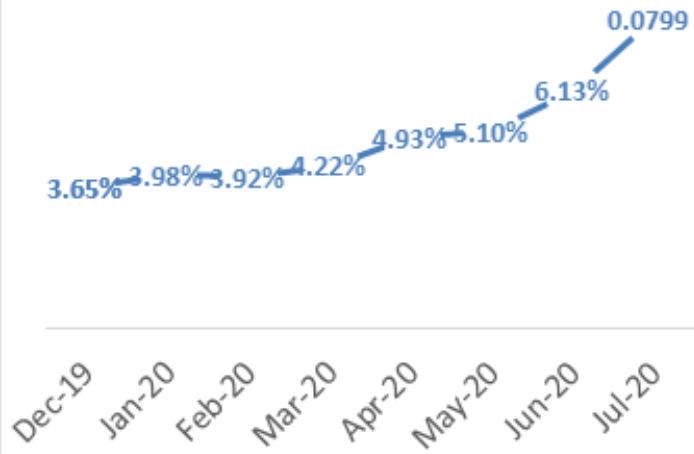

Grafik 1. Peningkatan Ratio Kualitas Pinjaman (TWP 90) 
Berdasarkan data statistik OJK periode Juli 2020 yang digambarkan pada grafik diatas, dapat dilihat bahwa terdapat peningkatan ratio kualitas pinjaman NPL (TWP 90). Untuk periode Desember 2019 ratio TWP 90 masih sebesar 3,65\% yang kemudian terus mengalami peningkatan sampai dengan $7,99 \%$ pada periode Juli 2020, sehingga menimbulkan kekhawatiran akan jika tidak ditangani segera oleh otoritas dalam hal ini Otoritas Jasa Keuangan (OJK).

Melihat dari grafik peningkatan ratio kualitas kredit bermasalah tersebut, selain dipengaruhi oleh faktor eksternal seperti pandemi Covid-19 yang terjadi di Indonesia sejak bulan Maret 2020, ditemukan pula bahwa faktor-faktor spesifik pinjaman dan karakteristik spesifik peminjam memainkan peran penting dalam penentuan tingkat pinjaman dan kualitas kredit dari pinjaman. Melalui POJK No. 77 /POJK.01/2016, Otoritas Jasa Keuangan hanya mewajibkan penyelenggara / perusahaan fintech lending terdaftar/berizin untuk melakukan mitigasi risiko baik itu risiko operasional dan risiko kredit. Mitigasi resiko kredit yang dimaksud termasuk pelaksanaan credit scoring yang meliputi penilaian terhadap karakteristik calon peminjam yang dapat dilihat dari data informasi kredit yang menampilkan track record pembayaran pinjaman calon peminjam dari sisi kedisiplinan pembayaran, catatan keterlambatan pembayaran dan jumlah pinjaman yang dimiliki. Hal ini dilakukan dengan tujuan untuk mencegah over indebtness borrower yang akan berdampak pada peningkatan ratio kredit bermasalah.

Namun yang menjadi persoalan saat ini adalah minimnya informasi yang dapat diterima oleh pemberi pinjaman dari penyelenggara peer to peer lending atas profil dari calon penerima pinjaman karena selama ini penyelenggara hanya memperoleh informasi kredit calon peminjam melalui sumber Fintech Data Center (FDC) dari penyelenggara fintech lending yang turut melaporkan data peminjamnya melalui Asosiasi Fintech Pendanaan Bersama Indonesia (AFPI), sehingga hal ini dirasa masih dapat menjadi potensi pada resiko gagal bayar peminjam karena kurang tepatnya analisis terhadap profil peminjam. Berbeda dengan dengan sifat pinjaman dari bank yang menerapkan prinsip 5C, yakni Character, Capacity, Capital, Collateral, Condition sebagai acuan kelayakan. Peer to Peer Lending sejatinya harus benar-benar menekankan prinsip character calon penerima pinjaman disamping capacity atau kemampuan bayar debitur yang dapat dilakukan dengan memaksimalkan penilaian terhadap karakter calon peminjam melalui informasi kredit yang komprehensif.

Pada tahap pendalaman informasi karakter dan kredibilitas debitur ini sebenarnya diperlukan suatu integrasi data keuangan atas calon peminjam yang lebih komprehensif selain dari Fintech Data Centre yang dikelola AFPI yaitu melalui suatu sistem layanan informasi keuangan yang dikelola oleh OJK yaitu SLIK OJK yang akan memberikan informasi kredit debitur selama 1 (satu) tahun terakhir yang berasal dari lembaga keuangan dan data non lembaga keuangan. Terkait hal ini, OJK memang tidak mewajibkan kepada penyelenggara fintech lending untuk menjadi anggota dari SLIK OJK sebagaimana diatur dalam Pasal 22 POJK No. 77 /POJK.01/2016 karena ada beberapa persyaratan yang harus dipenuhi untuk dapat menjadi anggota

Berdasarkan latar belakang yang telah diuraikan tersebut, maka penulis mengangkat permasalahan tentang bagaimana pelaksanaan Fintech peer to peer lending di Indonesia serta bagaimana bentuk pengawasan yang dilakukan OJK untuk meminimalisasi risiko kredit NPL serta relevansinya terhadap kewajiban pelaporan informasi debitur melalui Sistem Layanan Informasi Keuangan (SLIK) OJK.

\section{METODE PENELITIAN}

Metode penelitian yang digunakan dalam upaya pengumpulan data atau bahan merupakan suatu syarat penting dalam suatu penelitian hukum yang bersifat ilmiah, yang kemudian akan dipergunakan sebagai bahan dari penelitian materi tersebut. Metode merupakan suatu kegiatan ilmiah yang berkaitan dengan suatu cara kerja yang sistematis untuk memahami/menganalisa suatu obyek atau isu dalam penelitian, sebagai upaya dalam menemukan jawaban yang dapat 
dipertanggungjawabkan secara ilmiah untuk keabsahannya. Dalam penelitian ini akan menggunakan metode penelitian hukum normatif, yang akan melakukan penelitian terhadap berbagai aturan hukum yang terkait. Metode penelitian hukum adalah metode yang mengacu pada hukum dan peraturan perundangundangan yang berlaku, sedangkan metode penelitian normatif adalah metode yang dilakukan dengan cara meneliti bahan pustaka atau data sekunder terhadap terhadap asas-azas hukum serta studi kasus yang dengan kata lain disebut sebagai penelitian hukum kepustakaan. Selain itu juga akan digunakan pendekatan analitis untuk mengetahui makna yang dikandung oleh istilah-istilah yang digunakan dalam aturan perundang-undangan secara konsepsional, sekaligus mengetahui penerapannya dalam praktik.

\section{HASIL DAN PEMBAHASAN}

\section{Perkembangan Fintech Peer to Peer Lending di Indonesia}

Fintech telah mendapatkan momentum global, begitu juga di Indonesia. Hal ini tidak mengherankan mengingat Indonesia diperkirakan akan menjadi salah satu pasar ekonomi digital terbesar di Asia Tenggara pada tahun 2025. Dengan kelompok masyarakat berpendapatan menengah (middle income) yang terus tumbuh, potensi faktor demografi (porsi penduduk usia produktif yang besar), populasi pengguna teknologi digital yang makin besar, dan jumlah pengguna internet yang diperkirakan akan mencapai 200 juta pada tahun 2020, membuat peluang untuk tumbuhnya industri Fintech di Indonesia menjadi semakin prospektif. Fintech $P 2 P$ lending adalah salah satu bentuk inovasi keuangan digital di sektor keuangan dimana yang termasuk inovasi keuangan haruslah bersifat inovatif dan berorientasi ke depan, menggunakan teknologi informasi dan komunikasi sebagai sarana utama pemberian layanan kepada konsumen di sektor jasa keuangan, mendukung inklusi dan literasi keuangan, bermanfaat dan dapat dipergunakan secara luas, dapat diintegrasikan pada layanan keuangan yang telah ada, menggunakan pendekatan kolaboratif, dan memperhatikan aspek perlindungan konsumen dan perlindungan data.

Peer to peer lending adalah metode yang memungkinkan seorang peminjam dana, melalui aplikasi atau situs mengajukan pinjaman tanpa jaminan (agunan). Berdasarkan POJK No. 77/POJK.01/2016 tentang Layanan Pinjam Meminjam Uang Berbasis Teknologi Informasi atau dikenal peer to peer lending diartikan sebagai berikut:

"Layanan Pinjam Meminjam Uang Berbasis Teknologi Informasi adalah penyelenggaraan layanan jasa keuangan untuk mempertemukan pemberi pinjaman dengan penerima pinjaman dalam rangka melakukan perjanjian pinjam meminjam dalam mata uang rupiah secara langsung melalui sistem elektronik dengan menggunakan jaringan internet."

Sistem peer to peer lending merupakan pola interaksi keuangan dalam Fintech antara pihak penyedia dana dan pihak peminjam dana yang transaksinya dilakukan secara online. Fintech sistem P2P Lending, bukan hanya sekedar memfasilitasi mereka yang membutuhkan pinjaman dana, tetapi juga diperuntukan bagi investor yang ingin menanamkan modalnya dalam jumlah tertentu. Sehingga perusahaan Fintech menjadi wadah yang mempertemukan antara pemberi pinjaman (calon kreditur) dan peminjam (calon debitur) melalui aplikasi secara on-line.

Menurut data statistik dari OJK, Fintech peer to peer lending menunjukkan trend yang sangat positif, tercatat hingga bulan Juli 2020 akumulasi penyaluran pinjaman melalui peer to peer lending di Indonesia telah mencapai Rp 116,97 Triliun atau meningkat sebesar $134,91 \%$ dari periode yang sama tahun sebelumnya. Perkembangan Fintech Lending lebih lanjut akan ditampilkan dalam bagan dibawah ini

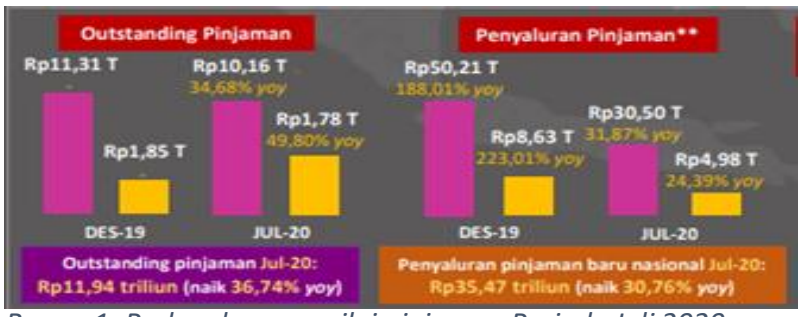

Bagan 1. Perkembangan nilai pinjaman Periode Juli 2020 
Melalui bagan ini dapat dilihat bahwa perkembangan dari Fintech Lending sangat pesat dalam mendukung peningkatan inklusi keuangan Indonesia. Pertumbuhan penyaluran pinjaman baru meningkat pada periode Juli 2020 hingga Rp.35,47 Triliun atau meningkat sebesar 30,76\% dibandingkan periode Juli 2019 (yoy).

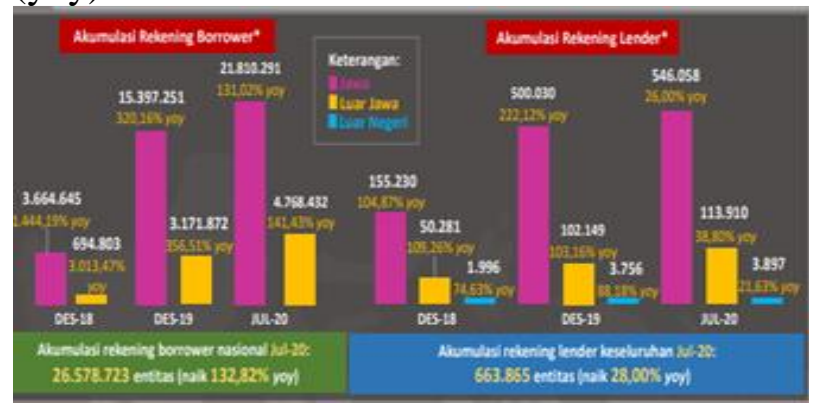

Hal ini tentu saja sejalan dengan peningkatan jumlah rekening penerima pinjaman/lender yang meningkat sebesar $28 \%$ dari periode sebelumnya. Dari sisi pihak yang melakukan investasi melalui pemberian pinjaman, dapat dilihat pula peningkatan rekening pemberi pinjaman/borrower sebesar $132,82 \%$ yoy dengan akumulasi peningkatan borrower aktif sebesar $9,71 \%$ atau meningkat sebesar $99,16 \%$ yoy yang didominasi oleh borrower yang berasal dari Jawa.

Namun tidak kalah penting untuk diperhatikan pada bagan dibawah ini juga dapat dilihat bahwa disamping peningkatan yang telah disebutkan sebelumnya, ratio kualitas kredit atau tingkat keberhasilan bayar 90 hari (TKB 90 hari) justru mengalami penurunan dari semula 96,35\% periode Desember 2019 menjadi 92,01\% pada bulan Juli 2020.

Bagan 3. Penurunan Tingkat Keberhasilan Bayar 90 hari (TKB90)

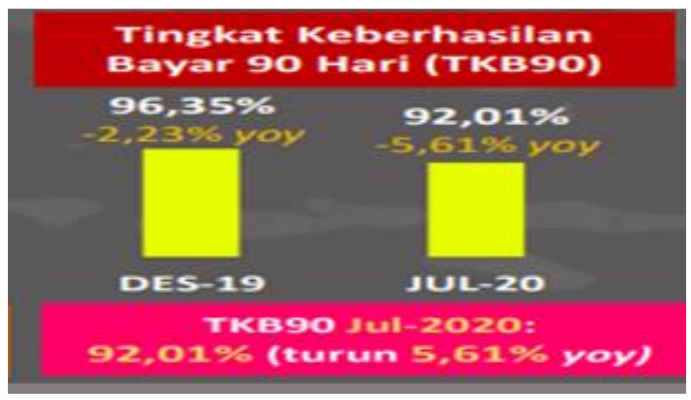

Sumber dari Data Statistik OJK Juli 2020

Hal ini menunjukan bahwa peningkatan pada nilai pinjaman dan jumlah rekening peminjam tidak selaras dengan ratio kualitas kredit yang lancar sehingga hal ini perlu menjadi perhatian bagi para penyelenggara fintech lending dan pemberi pinjaman sebagai investor.

Seperti kita ketahui, peer to peer lending memiliki manfaat atau kelebihan jika dibandingkan dengan mengajukan pinjaman kepada lembaga keuangan resmi.Meskipun demikian, terdapat juga kekurangan pada proses bisnis peer to peer lending antara lain:

a. Bagi penerima pinjaman, tidak ada pengaturan khusus tentang penerapan suku bunga sehingga suku bunga pinjaman peer to peer Lending dapat melonjak naik saat kelayakan kredit Peminjam jatuh dan cenderung sedikit lebih tinggi dibanding suku bunga pinjaman perbankan dan hal ini dapat merugikan penerima pinjaman.

b. Bagi pemberi pinjaman :

a) Informasi mengenai prosedur dan tata cara penilaian kredit oleh perusahaan penyedia layanan atau penyelenggara sering kurang dijelaskan dengan lengkap.

b) Keseluruhan proses pinjam meminjam tidak dijamin oleh asuransi, meskipun dalam perkembangannya saat ini penyelenggara sudah menyediakan alternatif jaminan asuransi atas dana yang diserahkan oleh pemberi pinjaman.

Namun dalam penulisan jurnal ini, penulis akan lebih membahas sisi kekurangan dari peer to peer lending bagi pemberi pinjaman sehubungan dengan risiko kredit yang dapat ditimbulkan atas kekurangan pengaturan atas pemberian pinjaman bagi borrower atau pemberi pinjaman berkaitan dengan penilaian kredit terhadap calon penerima pinjaman.

\section{Peningkatan Risiko Kredit NPL (TWP 90) Fintech Peer to Peer Lending}

Sebagai sebuah alternatif produk keuangan, selayaknya investasi pada umumnya, memberikan dana di Peer to Peer Lending pun tetap memiliki risikonya tersendiri, salah satunya yaitu risiko kredit bermasalah atau biasa dikenal di dunia perbankan sebagai NonPerforming Loan (NPL) atau kredit macet. Risiko ini dianggap sebagai risiko terbesar dari penyelenggaraan peer to peer pending yang akhirnya menyebabkan kerugian terhadap para investor/ borrower atau pemberi pinjaman. Meskipun demikian, risiko kredit ini dapat 
diminimalisir dengan tindakan preventif dari pemberi pinjaman, antara lain: pengecekan data oleh pemberi pinjaman apakah perusahaan penyedia layanan Peer to Peer Lending telah menyeleksi Peminjam dengan indikator tertentu untuk memastikan bahwa pinjaman yang ditawarkan merupakan pinjaman yang berkualitas dan diajukan oleh peminjam/ lender yang feasible atau layak untuk menerima pinjaman.

Namun yang menjadi persoalan saat ini adalah minimnya informasi yang dapat diterima oleh pemberi pinjaman dari penyelenggara peer to peer lending atas profil dari calon penerima pinjaman yang dapat berakibat pada resiko gagal bayar peminjam karena kurang tepatnya analisis terhadap profil calon penerima pinjaman. Berbeda dengan dengan sifat pinjaman dari bank yang menerapkan prinsip 5C, yakni Character, Capacity, Capital, Collateral, Condition sebagai acuan kelayakan. Peer to Peer Lending yang memiliki kelebihan karena tidak memerlukan collateral atau agunan sejatinya harus memperhatikan prinsip character calon penerima pinjaman sebelum melihat capacity atau kemampuan bayar calon penerima pinjaman/borrower.

Sama halnya pada saat pemberian pinjaman oleh bank, karakter tidak diragukan lagi adalah faktor yang sangat penting untuk dipertimbangkan jika ingin memberikan kredit. Apabila debitur tidak jujur, curang, ataupun incompetence, maka kredit tidak akan berhasil tanpa perlu memperhatikan faktor-faktor lainnya. Orang yang tidak jujur ataupun curang akan selalu mencari jalan untuk mengambil keuntungan. Seseorang yang incompetence menjalankan bisnis tidak diragukan lagi akan menjalankan bisnisnya dengan buruk, dan hasilnya kredit akan mengandung resiko tinggi. Jika seseorang tidak ingin membayar kembali kreditnya, kemungkinan ia akan mencari jalan untuk menghindari membayar kembali. Untuk itu, penilaian karakter debitur harus ditentukan sejak ia memulai langkah pertama untuk mendapatkan pinjaman.

Dalam hal ini penyelenggara peer to peer lending masih belum menerapkan prinsip KYC (Know Your Costumer) yang biasanya dilakukan bank untuk mengetahui identitas nasabah, memantau kegiatan transaksi nasabah termasuk pelaporan transaksi yang mencurigakan. Penyelenggara peer to peer lending hanya dapat melaksanakan e-KYC untuk dapat mengenal pengguna yang bertransaksi tanpa tatap muka secara langsung dengan penyedia layanan. Sebagaimana diatur dalam POJK No. 23 /POJK.01/2019 tentang Perubahan atas POJK Nomor 12/POJK.01/2017 tentang Penerapan Program Anti Pencucian Uang dan Pencegahan Pendanaan Terorisme di Sektor Jasa Keuangan, pada pasal 17 disebutkan bahwa penyelenggara fintech peer to peer lending sebagai salah satu penyedia jasa keuangan (PJK) di sektor industri keuangan non bank diwajibkan untuk melakukan identifikasi dan verifikasi calon nasabah baik secara langsung atau melalui proses dan sarana elektronik milik PJK atau milik pihak ketiga, untuk mengetahui profil calon penerima pinjaman/ borrower berdasarkan atas informasi dan dokumen pendukung calon borrower.

Namun demikian, penilaian karakter calon penerima pinjaman untuk menghindari risiko salah pemberian kredit yang dapat meningkatkan ratio kualitas pinjaman NPL (TWP 90), tidak dapat dilakukan hanya dengan melaksanakan e-KYC, penyelenggara wajib melakukan penilaian kredit/ credit scoring terhadap data yang diperoleh terkait calon penerima pinjaman. Berkaitan dengan hal tersebut, akurasi data dan ketersediaan data yang lengkap mencakup historikal kredit calon penerima pinjaman sangatlah memiliki peranan penting untuk analisis kelayakan pemberian pinjaman sehingga dapat meminimalisasi risiko kredit NPL pada industri peer to peer lending.

\section{Penunjukan AFPI sebagai bentuk pengawasan OJK terhadap Fintech Peer to Peer Lending}

Otoritas Jasa Keuangan (OJK) adalah lembaga independen yang berfungsi menyelenggarakan sistem pengaturan dan pengawasan yang terintegrasi terhadap keseluruhan kegiatan di dalam sektor jasa keuangan. Adapun Perusahaan Fintech dengan skema peer to peer lending merupakan lingkup kewenangan OJK dikarenakan perusahaan 
tersebut memberikan pelayanan produk dan jasa keuangan. Sebagaimana dalam Pasal 6 UU tentang OJK disebutkan bahwa pelaksanakan tugas pengaturan dan pengawasan dilakukan terhadap kegiatan jasa keuangan di sektor Perbankan, sektor Pasar Modal, sektor Perasuransian, Dana Pensiun, Lembaga Pembiayaan, dan Lembaga Jasa Keuangan Lainnya. Penyelenggara fintech peer to peer lending dengan bentuk perusahaan berupa badan hukum perseroan terbatas dan koperasi dinyatakan sebagai Lembaga Jasa Keuangan Lainnya sesuai dengan Pasal 2 ayat (2) POJK No. 77/ POJK.01/2016 tentang Layanan Pinjam Meminjam Uang Berbasis Teknologi Informasi sehingga jelaslah bahwa penyelenggara peer to peer lending termasuk dalam lingkup pengawasan Otoritas Jasa Keuangan yakni dibawah pengawasan Kepala Eksekutif IKNB OJK.

Adapun OJK melakukan pengawasan terhadap Penyelenggara Fintech Lending melalui 3 (tiga) metode, yaitu:

a. Offsite, melalui laporan-laporan yang disampaikan kepada dan juga rencana implementasi host-to-host dengan server Perusahaan dengan memanfaatkan Struktur Elemen Database

b. Market Conduct (Semi SRO), sesuai ketentuan Pasal 48, seluruh Penyelenggara wajib terdaftar sebagai anggota asosiasi yang telah ditunjuk oleh OJK. OJK telah menunjuk Asosiasi Fintech Pendanaan Bersama Indonesia (AFPI) pada tanggal 17 Januari 2019. AFPI memiliki Code of Conduct dan memberikan beberapa pengaturan yang belum diatur OJK, diantaranya batas maksimal bunga dan tata cara penagihan. OJK rutin bertemu AFPI minimal 1 kali setiap minggu.

c. Onsite, melalui mekanisme pemeriksaan langsung baik yang dilakukan secara rutin maupun sewaktu-waktu.

Saat ini, Otoritas Jasa Keuangan telah mengeluarkan 2 (dua) peraturan yang berkaitan dengan Peer to Peer Lending, yakni Peraturan Otoritas Jasa Keuangan Nomor 77/POJK.01/2016 tentang Pinjam Meminjam Uang Berbasis Teknologi Informasi dan Surat Edaran Otoritas Jasa Keuangan Nomor
18/SEJOK.01/2017 tentang Tata Kelola dan Manajemen Risiko Teknologi Informasi pada Layanan Pinjam Meminjam Uang Berbasis Teknologi Informasi. Namun sayangnya, POJK tentang peer to peer lending ini hanya memberikan panduan dalam pelaksanaan bisnis financial technology berbasis usaha pinjammeminjam, seperti pengaturan terkait kegiatan usaha, pendaftaran perizinan, mitigasi risiko, pelaporan, dan tata kelola sistem teknologi informasi. Pengawasan OJK terhadap penyelenggara fintech lending pada POJK tersebut hanya berupa kewajiban penyampaian laporan berkala secara elektronik dan rekam jejak audit terhadap seluruh kegiatan penyelenggara fintech lending. Pengawasan dalam bentuk seperti ini dirasa belum mumpuni, karena dalam hal terjadi resiko kredit bermasalah atau resiko gagal bayar dari penerima pinjaman yang berimplikasi terhadap kerugian dari pihak pemberi pinjaman.

Terkait mitigasi risiko, POJK tentang peer to peer lending ini hanya mengatur tentang keharusan bagi Penyelenggara dan Pengguna (pemberi dan penerima pinjaman) untuk melakukan mitigasi risiko sebagaimana disebutkan pada pasal 21, mencakup seluruh risiko yang terdapat dalam Layanan Pinjam Meminjam Uang Berbasis Teknologi Informasi, antara lain risiko operasional dan risiko kredit. Untuk risiko operasional, OJK telah mengeluarkan Surat Edaran OJK No. 18 /SEOJK.02/2017 tentang Tata Kelola dan Manajemen Risiko Teknologi Informasi Pada Layanan Pinjam Meminjam Uang Berbasis Teknologi Informasi. Namun OJK tidak memiliki pengaturan sendiri terkait dengan risiko yang dapat terjadi atas pelaksanaan peer to peer lending sehingga manajemen risiko khususnya risiko kredit sepenuhnya menjadi tanggung jawab dari penyelenggara dan pengguna baik itu pemberi pinjaman dan penyedia pinjaman sebagai bagian dari risiko bisnis dan investasi.

Untuk memahami kompleksitas pemanfaatan digital pada sektor keuangan, khususnya peer to peer lending, Otoritas Jasa Keuangan (OJK) telah menerapkan pendekatan ruang uji terbatas (regulatory sandbox) yang memungkinkan OJK untuk mengawasi model 
bisnis inovator sebelum memberikan izin. Selain itu, OJK juga menggunakan pendekatan light touch regulation dan memberlakukan principle-based regulation dimana OJK menunjuk Asosiasi Fintech Pendanaan Bersama Indonesia (AFPI) sebagai asosiasi Fintech Lending di Indonesia. Penunjukan dilakukan melalui surat S5/D.05/2019 tanggal 17 Januari 2019. Pada tanggal 8 Maret 2019 dilakukan persemian AFPI oleh OJK.

Pada penyelenggaraan inovasi keuangan digital, OJK memang hanya membuat garis besar pengaturan, sementara teknis dari pengaturan tersebut dibuat oleh para pelaku industri. Dengan demikian, asosiasi memiliki peran penting untuk merumuskan standar industri dan mengembangkan operasional Asosiasi Penyelenggara Inovasi Keuangan Digital, termasuk pedoman perilaku model bisnis masing-masing anggota. Dengan menjalankan code of conduct dan code of ethics, tercipta mekanisme pengawasan mandiri dan saling mengawasi antar penyelenggara inovasi keuangan digital. Dengan demikian sebagai bentuk pengawasan yang diberikan OJK, AFPI memiliki Code of Conduct dan memberikan beberapa pengaturan yang belum diatur OJK, diantaranya batas maksimal bunga dan tata cara penagihan. Adapun seluruh penyelenggara peer to peer lending yang saat ini berjumlah 158 penyelenggara terdaftar/berizin dari OJK diwajibkan untuk terdaftar sebagai anggota asosiasi AFPI sebagaimana diatur dalam pasal 48 POJK No.77/POJK.01/2016. Pertemuan OJK dengan AFPI dilakukan secara rutin minimal 1 kali setiap minggu.

Pada akhir tahun 2019, AFPI juga telah meluncurkan pusat data fintech lending (FDC) yang dikelola secara independen oleh AFPI, khusus untuk kepentingan para penyelenggara fintech lending yang menjadi anggota AFPI. Fintech data center ini juga dibuat dengan tujuan untuk memastikan industri fintech peer to peer lending di Indonesia lebih sehat, menghindari potensi kredit macet, serta menghindari fraud dengan cara mengidentifikasi potensi fraud. Dengan melakukan akses ke FDC, diharapkan para penyelenggara fintech lending yang legal dapat menjaga kualitas pinjaman mereka dengan baik terlebih di saat pandemi Covid-19 yang tengah berlangsung ini. Adapun FDC mengelola data penerima pinjaman yang diperoleh hanya dari penyelenggara fintech lending legal atau yang telah mendapat izin dari OJK.

Dengan demikian dapat dilihat bahwa fungsi pengaturan dan pengawasan OJK terhadap pelaksanaan peer to peer lending lebih dimandatkan kepada AFPI dalam pengawasan terhadap penyelenggara fintech lending terdaftar/berizin. Hal ini dimaksudkan agar AFPI dapat menjadi wadah bagi seluruh penyelenggara fintech peer to peer lending, demi meningkatkan kapasitas bersama agar dapat memaksimalkan fungsinya bagi masyarakat Indonesia yang selama ini belum memiliki akses ke jasa keuangan konvensional dengan tetap memperhatikan perlindungan kepada konsumen atau pengguna dari peer to peer lending baik itu pemberi pinjaman maupun penerima pinjaman.

\section{Minimalisasi Risiko Kredit NPL (TWP 90) pada Fintech Peer to Peer Lending melalui Kewajiban Pelaporan SLIK OJK}

Sebagaimana diketahui, keberadaan Fintech lending merupakan salah satu solusi dari inklusi keuangan di Indonesia. Berdasarkan Survei Nasional Literasi Keuangan (SNLIK) ketiga yang dilakukan Otoritas Jasa Keuangan (OJK) indeks literasi keuangan mencapai $38,03 \%$ dan indeks inklusi keuangan $76,19 \%$. Angka tersebut meningkat dibanding hasil survei OJK 2016 yaitu indeks literasi keuangan $29,7 \%$ dan indeks inklusi keuangan $67,8 \%$. Dengan demikian dalam 3 tahun terakhir terdapat peningkatan pemahaman keuangan (literasi) masyarakat sebesar 8,33\%, serta peningkatan akses terhadap produk dan layanan jasa keuangan (inklusi keuangan) sebesar 8,39\% sehingga target indeks inklusi keuangan yang dicanangkan pemerintah melalui Perpres Nomor 82 tahun 2016 tentang Strategi Nasional Keuangan Inklusif (SNKI) sebesar $75 \%$ pada tahun 2019 telah tercapai. Berkaitan dengan pencapaian tersebut, kontribusi fintech peer to peer lending sangatlah besar dalam peningkatan inklusi keuangan di Indonesia.

$\begin{array}{rrrr}\text { Berdasarkan } & \text { data Otoritas } & \text { Jasa } \\ \text { Keuangan } & \text { (OJK) } & \text { periode Juli } & \text { 2020, }\end{array}$


perkembangan pesat dari akumulasi penyaluran pinjaman melalui peer to peer lending di Indonesia telah mencapai Rp 116,97 Triliun atau meningkat sebesar $134,91 \%$ dari periode yang sama tahun sebelumnya. Namun hal ini tidak didukung dengan peningkatan maupun kestabilan dari kualitas pinjaman lancar (TKB90) yang justru terus mengalami penurunan dari semula $96,35 \%$ periode Desember 2019 menjadi 92,01\% pada bulan Juli 2020. Dengan kata lain, terjadi peningkatan ratio kredit NPL (TWP90) pada periode Juli menjadi 7,99\% 2020 dari ratio 3,65\% pada periode Desember 2019. Peningkatan ratio kredit TWP90 ini beriringan dengan peningkatan nilai pinjaman dan jumlah rekening pinjaman baru sehingga hal ini hendaknya menjadi perhatian bagi pengawas dalam hal ini OJK dan AFPI.

Adapun peningkatan ratio kredit NPL tersebut terus meningkat selain karena dipengaruhi oleh faktor eksternal pandemi Covid-19 yang mulai terjadi pada awal Maret 2020, faktor lain yang turut menjadi penyebab adalah akurasi dari penilaian kredit (credit scoring) yang dilakukan oleh penyelenggara fintech lending. Sebagaimana kita ketahui, keunggulan dari layanan pinjam meminjam peer to peer lending terletak pada tidak dibutuhkannya jaminan tambahan dalam proses pemberian kredit sehingga penilaian karakter calon penerima pinjaman menjadi sangat penting dan utama disamping penilaian kemampuan (capacity) calon penerima pinjaman. Terkait dengan penilaian karakter calon penerima pinjaman tersebut, dibutuhkan data yang dapat menampilkan track record dari calon penerima pinjaman untuk dapat menilai kelayakan dan kredibilitas agar dapat menerima pinjaman dari pemberi pinjaman. Namun yang menjadi persoalan saat ini adalah penggunaan sumber data untuk penilaian calon penerima pinjaman hanya mengandalkan data yang dikumpulkan oleh AFPI pada Fintech Data Center (FDC). Hal ini dikarenakan FDC hanya dapat memberikan data yang lengkap tentang penerima pinjaman yang memiliki pinjaman pada penyelenggara fintech lending menjadi anggota AFPI.
Padahal pada tahap pendalaman informasi karakter dan kredibilitas debitur ini sebenarnya diperlukan suatu integrasi data keuangan atas calon peminjam yang lebih komprehensif selain dari Fintech Data Centre yang dikelola AFPI yaitu melalui suatu sistem layanan informasi keuangan yang dikelola oleh OJK yaitu SLIK OJK yang akan memberikan informasi kredit debitur selama 1 (satu) tahun terakhir yang berasal dari lembaga keuangan dan data non lembaga keuangan. Terkait hal ini, sangat disayangkan bahwa OJK tidak mewajibkan kepada penyelenggara fintech lending untuk menjadi anggota dari SLIK OJK sebagaimana diatur dalam Pasal 22 POJK No. 77 /POJK.01/2016 bahwa "Penyelenggara dapat menjadi anggota sistem layanan informasi keuangan OJK atau sistem layanan informasi lainnya yang terdaftar di OJK dengan memenuhi persyaratan sesuai dengan ketentuan peraturan perundang-undangan." Lebih lanjut pada pasal 3 ayat (1) POJK No. 18 /POJK.03/2017 tentang Pelaporan dan Permintaan Informasi Debitur Melalui Sistem Layanan Informasi Keuangan disebutkan bahwa "Lembaga Jasa Keuangan Lainnya yang menyediakan layanan pinjammeminjam uang berbasis teknologi informasi dan lembaga keuangan mikro dapat menjadi Pelapor dengan mengajukan permohonan dan mendapat persetujuan OJK dengan memenuhi persyaratan:

a. memiliki infrastruktur yang memadai;

b. memiliki data yang diperlukan dalam SLIK; dan

c. menandatangani perjanjian keikutsertaan dalam pelaporan dan permintaan Informasi Debitur melalui SLIK.

Oleh karenanya sangat disayangkan bahwa OJK tidak melaksanakan fungsi pengaturan dan pengawasan terhadap penyelenggara fintech lending dalam pencegahan risiko kredit bermasalah dengan memberikan aturan mengenai kewajiban menjadi anggota SLIK bagi penyelenggara fintech lending agar akses terhadap informasi perkreditan calon penerima pinjaman bahkan calon pemberi pinjaman dapat diperoleh. Adapun informasi perkreditan yang dihasilkan oleh LPIP yang merupakan lembaga yang menghimpun dan mengolah data kredit dan data 
lain untuk menghasilkan informasi perkreditan disebutkan pada Pasal 4 POJK No. 42 /POJK.03/2019 tentang Lembaga Pengelola Informasi Perkreditan (LPIP), memuat:

a. kelayakan Debitur atau Nasabah untuk memperoleh Fasilitas Penyediaan Dana

b. rekam jejak reputasi Debitur atau Nasabah dalam memenuhi kewajiban penyediaan dana;

c. kemampuan Debitur atau Nasabah untuk memenuhi kewajiban penyediaan dana;

d. karakter Debitur atau Nasabah;

e. informasi lain yang dapat digunakan untuk menilai kemampuan Debitur atau Nasabah.

Seperti dijelaskan sebelumnya mengenai risiko kredit NPL (TWP90) dipengaruhi oleh salah satu faktor yaitu karakter dari penerima pinjaman. Penilaian karakter peminjam meliputi aspek kompetensi, identifikasi, kematangan sosial dan keuangan, kejujuran dan tanggung jawab. Hal ini bukan sesuatu yang mudah untuk dilakukan. Bank misalnya, harus mampu menilai bahwa calon debitur adalah orang yang jujur dan dapat diandalkan. Untuk itu, bank membutuhkan track record dari debitur yang bersangkutan. Salah satu sumber yang dapat digunakan untuk memperoleh informasi lengkap, akurat dan terkini tentang seorang calon debitur adalah melalui biro kredit yang saat ini dapat diperoleh dari Sistem Layanan Informasi Keuangan (SLIK) sebagai sistem informasi yang dikelola oleh OJK untuk mendukung pelaksanaan tugas pengawasan dan layanan informasi di bidang keuangan. Dalam POJK NO. 18 /POJK.03/2017 tentang Pelaporan dan Permintaan Informasi Debitur Melalui Sistem Layanan Informasi Keuangan, pada pasal 4 ayat (2) disebutkan bahwa informasi debitur yang dilaporkan meliputi debitur, fasilitas Penyediaan Dana; agunan, penjamin, pengurus dan pemilik; dan keuangan Debitur.

Kemudahan akses perkreditan atau pembiayaan merupakan salah satu aspek penting dalam menciptakan sistem keuangan yang sehat dalam rangka mendukung pertumbuhan ekonomi suatu negara. Kemudahan akses perkreditan atau pembiayaan perlu didukung dengan adanya sistem informasi yang berfungsi sebagai sarana pertukaran informasi kredit antar lembaga jasa keuangan. Sesuai dengan ketentuan peraturan perundangundangan, Otoritas Jasa Keuangan diberikan kewenangan untuk mengatur dan mengembangkan penyelenggaraan sistem informasi antar bank yang dapat diperluas dengan menyertakan lembaga lain di bidang keuangan.

Adapun berbeda dengan SID atau BI Checking yang sebelumnya, dengan adanya SLIK, tidak hanya bank dan lembaga pembiayaan yang punya akses, kini lembaga keuangan keuangan non bank punya akses dan kewajiban melaporkan data debitur. Melalui hal ini diharapkan rasio kredit bermasalah (NPL) diharapkan bisa diminimalkan dengan optimalisasi penggunaan informasi pada SLIK OJK. Dalam perkembangan digitalisasi ekonomi saat ini diharapkan agar fintech lending juga dapat mengikuti salah satu proses penting dalam analisa kredit seperti bank yaitu penilaian terhadap karakter calon penerima pinjaman dengan menggunakan informasi perkreditan yang disajikan oleh SLIK OJK. Sebelumnya, fintech lending menjalin kerja sama dengan perusahaan sejenis untuk bertukar data mengenai nasabah yang kreditnya bermasalah yang kemudian berkembang menjadi Fintech Data Center yang dikelola oleh asosiasi resmi OJK, AFPI. Selain itu, digunakan pula jasa pemeringkat kredit untuk menilai kelayakan nasabah bahkan sebagian memanfaatkan teknologi seperti kecerdasan buatan (artificial intelligence/AI) untuk meminimalkan risiko pembiayaan.

Sebagaimana dijelaskan sebelumnya, pelaporan penyelenggara fintech lending melalui SLIK OJK masih bersifat sukarela, dan masih akan diwajibkan per 31 Desember 2022. Padahal pelaporan data akan menciptakan sektor keuangan yang kuat dan perkreditan yang sehat dengan dihasilkannya analisis dan pengambilan keputusan yang tepat saat akan memberikan pinjaman/kredit atau pembiayaan. Perkembangan yang sangat signifikan pada industry fintech peer to peer lending turut meningkatkan kebutuhan untuk mengelola risiko dengan lebih baik, meminimalkan adverse selection serta moral hazard dalam penyediaan dana oleh pemberi pinjaman melalui 
penyelenggara fintech lending membutuhkan data dan layanan informasi calon peminjam yang komprehensif, dan terintegrasi dengan ragam produk dan layanan Informasi Perkreditan yang dapat ditemukan pada Sistem Layanan Informasi Keuangan (SLIK) OJK. Dengan demikian, diharapkan fungsi pengawasan dan pengaturan dari OJK dapat terlihat dari percepatan kebijakan perihal kewajiban terhadap pelaporan informasi pada SLIK OJK bagi penyelenggara fintech peer to peer lending demi pertumbuhan penyaluran pinjaman yang terjaga dengan baik kualitas kreditnya.

\section{KESIMPULAN}

Perkembangan dari fintech peer to peer lending sangat pesat dalam mendukung peningkatan inklusi keuangan Indonesia terlihat dari peningkatan penyaluran pinjaman baru pada periode Juli 2020 hingga Rp.35,47 Triliun atau meningkat sebesar 30,76\% dibandingkan periode Juli 2019 dengan akumulasi penyaluran pinjaman sebesar Rp.116,97 Triliun atau meningkat sebesar $134,91 \%$ dari periode Juli 2019. Hal ini tentu saja sejalan dengan peningkatan jumlah rekening penerima pinjaman/lender yang meningkat sebesar $28 \%$ dari periode sebelumnya Namun, disamping peningkatan nilai pinjaman tersebut, ratio kualitas kredit lancar atau tingkat keberhasilan bayar 90 hari (TKB 90 hari) justru mengalami penurunan dari semula $96,35 \%$ periode Desember 2019 menjadi 92,01\% pada bulan Juli 2020. Hal ini menunjukan bahwa peningkatan pada nilai pinjaman dan jumlah rekening peminjam justru menghasilkan peningkatan pada ratio kualitas kredit bermasalah/NPL (TWP90) menjadi $7,99 \%$ pada periode Juli 2020, sehingga hal ini menimbulkan kekhawatiran jika tidak ditangani segera oleh otoritas dalam hal ini Otoritas Jasa Keuangan (OJK).

Pengawasan OJK terhadap penyelenggara fintech lending pada POJK tersebut berupa kewajiban penyampaian laporan berkala secara elektronik dan rekam jejak audit terhadap seluruh kegiatan penyelenggara fintech lending. Selain itu, OJK juga menggunakan pendekatan light touch regulation dan memberlakukan principle-based regulation dimana OJK menunjuk Asosiasi Fintech Pendanaan Bersama Indonesia (AFPI) sebagai asosiasi Fintech Lending di Indonesia. Sebagai bentuk pengawasan preventif dari AFPI, dibentuk pusat data fintech lending (FDC) yang dikelola secara independen oleh AFPI, khusus untuk kepentingan para penyelenggara fintech lending yang menjadi anggota AFPI dengan menyediakan data terkait penerima pinjaman yang pada penyelenggara fintech lending menjadi anggota AFPI dengan tujuan agar para penyelenggara fintech lending yang terdaftar/berizin dapat menjaga kualitas pinjaman yang disalurkan.

Melihat peningkatan ratio NPL (TWP90) pada penyelenggara fintech lending, dapat dikatakan bahwa akses informasi calon peminjam melalui FDC masih kurang efektif dalam menimalisasi risiko kredit dikarenakan data maupun informasi yang dimiliki hanya meliputi penyelenggara fintech lending terdaftar/berizin, berbeda dengan informasi perkreditan yang dikelola oleh SLIK OJK yang menampilkan lembaga keuangan bank dan non bank. Adapun OJK tidak mewajibkan kepada penyelenggara fintech lending untuk menjadi anggota dari SLIK OJK sebagaimana diatur dalam Pasal 22 POJK No. 77 /POJK.01/2016 padahal dengan menjadi anggota SLIK OJK, akses penyelenggara fintech lending terhadap informasi perkreditan calon penerima pinjaman dapat lebih optimal dan dapat berdampak pada minimnya risiko kredit NPL (TWP90).

\section{SARAN}

Meski memiliki potensi yang besar dalam meningkatkan inklusi keuangan Indonesia, Fintech P2P Lending juga perlu diatur secara hati-hati. Peran regulator sangat dibutuhkan untuk mendorong ekosistem usaha yang sehat. Fintech peer to peer lending ini diyakini akan berkembang secara progresif dan dapat menjadi bagian dari solusi untuk mencapai pertumbuhan ekonomi Indonesia yang makmur dan sejahtera. Seiring dengan perkembangan fintech lending, risiko kredit yang ditimbulkan dari penyaluran pinjaman perlu diperhatikan. Penilaian karakter calon penerima pinjaman sebagai salah satu tindakan preventif untuk menimalisasi risiko 
kredit NPL (TWP90) membutuhkan akurasi data dan informasi perkreditan yang komprehensif, untuk itu diharapkan peraturan dari OJK yang mewajibkan agar penyelenggara fintech lending turut menjadi anggota SLIK OJK guna menghasilkan penilaian kredit (credit scoring) yang lebih baik dan akurat sehingga terjaga kualitas kredit dari pinjaman yang disalurkan.

Untuk memastikan optimalisasi peran dari Fintech bagi pertumbuhan ekonomi di masyarakat dan inklusi keuangan di Indonesia, maka diperlukan kajian mengenai bagaimana

\section{DAFTAR PUSTAKA}

Budiharto, Sartika, Gusto Hartanto, 2018, "The Legal Protection of Lender in Peer to Peer Lending System", Law Reform Program Studi Magister Ilmu Hukum Volume 15, Nomor 2, Universitas Diponegoro, (2019)

Darman, Financial Technology (Fintech): Karakteristik dan Kualitas Pinjaman pada Peer to Peer Lending di Indonesia, Jurnal Manajemen Teknologi, Fakultas Ekonomi dan Bisnis, Universitas Tadulako, Palu, Vol.18, No.2, Tahun 2019

Departemen Perlindungan Konsumen - Otoritas Jasa Keuangan, Kajian Perlindungan Konsumen Pada Fintech, Cetakan ke-1 : Desember 2017, www.ojk.go.id

Douglas, Drik, Ross, dkk, The Identity Challenge in Finance: From Analogue Identity to Digitized Identification to Digital KYC, Utilities European Business Organization Law Review (2019)

Hartanto, Ratna dan Juliyani Purnama Ramli, Hubungan Hukum Para Pihak dalam Peer to Peer Lending, Jurnal Hukum IUS QUIA IUSTUM NO. 2 VOL, Yogyakarta, ( 2018).

Heryucha Romanna Tampubolon, Seluk Beluk Peer to Peer Lending sebagai wujud baru keuangan di Indonesia, Jurnal $\mathrm{FH}$ UNPAD, Volume 3, Nomor 2, Maret 2019Atz, U., Bholat, D. Peer-to-Peer lending and financial innovation in the United Kingdom. World Bank Working mencapai keseimbangan antara kemudahan dan fleksibilitas layanan keuangan yang ditawarkan oleh Fintech dengan aspek perlindungan konsumennya termasuk pada Fintech peer to peer lending yaitu pemberi pinjaman. Sehubungan dengan hal tersebut, diharapkan pemerintah maupun OJK dapat memperkuat perannya dalam mengawasi Fintech dengan memperhatikan faktor-faktor utama seperti aspek keamanan, perlindungan konsumen, pelayanan, inklusivitas, dan mitigasi risiko yang dapat dituangkan dalam suatu regulasi yang komprehensif.

Paper. April 2016. Staff Working Paper No. 598. (2016). Marzuki, Peter Mahmud. Penelitian Hukum. (Jakarta: Prenadamedia Group, 2005.)

Magee, J. Peer-to-peer lending in the United States: surviving after Dodd-Frank. North Carolina Banking Institue Journal, (2011).

Otoritas Jasa Keuangan (OJK), Data Statistik

Ikhtisar Penyelenggaraan Fintech

Lending Periode Juli 2020,

www.ojk.go.id

Republik Indonesia, Undang-undang tentang Otoritas Jasa Keuangan, UU No.21 tahun 2011, LN No.111 tahun 2011, TLN No.5253

Republik Indonesia, Peraturan Otoritas Jasa Keuangan tentang Layanan Pinjam Meminjam Uang Berbasis Teknologi Informasi, POJK No. 77/POJK.01/2016, LN No.324 Tahun 2016, TLN No.6005

Republik Indonesia, Peraturan Otoritas Jasa Keuangan tentang Pelaporan dan Permintaan Informasi Debitur melalui Sistem Layanan Informasi Keuangan, POJK No. 18 /POJK.03/2017, LN No.93 Tahun 2017, TLN No.6049

Republik Indonesia, Peraturan Otoritas Jasa Keuangan tentang Lembaga Pengelola Informasi Perkreditan (LPIP) No. 42 /POJK.03/2019 LN No. 178 Tahun 2019, TLN No.6394

Republik Indonesia, Surat Edaran Otoritas Jasa Keuangan tentang Tata Kelola dan Manajemen Risiko Teknologi Informasi Pada Layanan Pinjam Meminjam Uang Berbasis Teknologi Informasi, SEOJK 
Terakreditasi Peringkat 4 (No. SK: 36/E/KPT/2019)

No. 18 /SEOJK.02/2017 tanggal 18 April 2017

Setiadi, Adi Saputra, Perlindungan Terhadap Pemberi Pinjaman Selaku Konsumen dan Tanggungjawab Penyelenggara Peer to Peer Lending dalam Kegiatan Peer To Peer Lending di Indonesia, Jurnal Universitas Katolik Parahyangan, Vol.5 No.1 , (2019)

Stallibrass, David and John Fingleton, Regulation, Innovation, and Growth: Why Peer-to-Peer Businesses Should Be Supported, Journal of European Competition Law \& Practice, Vol. 7, No. 6, (2016)

S., Kuzmina, Saksonova, , I., \& Merlino. Fintech as financial innovation - the possibilities and problems of implementation. European Research Studies Journal, XX (3A), (2017).

Widyaningsih, Nurul, Analisis Mitigasi Resiko Financial Technology Peer to Peer Lending Dalam Penyaluran Kredit Terhadap UMKM di Indonesia (Studi Kasus Pada PT. Amartha Mikro Fintek), Jurnal Ilmiah Universitas Brawijaya, (2018)

Van Loo, Rory, Making Innovation More Competitive: The Case of Fintech, U.C.L.A Law Review 232, (2018) 